\title{
Effect of Experimental Hyperinsulinaemia on Intracellular Glucose Metabolism of Isolated Adipocytes
}

\author{
M. Kobayashi ${ }^{1}$ and J. M. Olefsky ${ }^{2}$ \\ Department of Medicine, University of Colorado School of Medicine, and Denver Veterans Administration Hospital, \\ Denver, Colorado, USA
}

\begin{abstract}
Summary. Glucose oxidation and lipogenesis were studied in isolated adipocytes from control and nonobese, experimentally hyperinsulinaemic rats. In cells from the hyperinsulinaemic animals oxidation of either $\left[1-{ }^{14} \mathrm{C}\right]-$ or $\left[6-{ }^{14} \mathrm{C}\right]$ glucose was increased in the presence or absence of insulin, at substrate concentrations from 0.1 to $20 \mathrm{mmol} / \mathrm{l}$. Glucose incorporation into total triglycerides and fatty acids was also increased. These enhanced rates of glucose metabolism were due to increased activity of the glucose transport system in addition to increased activity of intracellular glucose metabolism. Therefore, these data indicate that insulin can influence long term glucose homoeostasis by augmenting the overall cellular capacity for glucose metabolism at several loci.
\end{abstract}

Key words: Hyperinsulinaemia, rat adipocytes, glucose oxidation, glucose transport, lipogenesis.

It has been previously suggested that long term elevation of the plasma insulin level will lead to decreased tissue responsiveness to insulin [1-3]. One mechanism for this has been proposed by Gavin et al. [4] who found that, in vitro, hyperinsulinaemia can lead to a loss of cellular insulin receptors. However, hormone-induced desensitization of a tissue to that hormone's effects can also involve attenuation of steps distal to receptor binding $[5,6]$. On this basis, one might speculate that in obesity it is the associated

\footnotetext{
${ }^{1}$ Dr. Kobayashi was an NIH Postdoctoral Trainee during the course of this work supported by NIH NIAMDD Training grant \#AM 07217

2 Dr. Olefsky was a Clinical Investigator with the Veterans Administration during the course of this work
}

hyperinsulinaemia that leads to the marked defects in glucose metabolism which have been described in enlarged adipocytes from obese rodents [7-13]. However, it has been demonstrated that short term (1-3 days) in vivo insulin treatment leads to augmented activity of several key glycolytic and lipogenic enzymes in rat liver and adipose tissue [14-17], and it seems possible that the effect of chronic hyperinsulinaemia per se is to induce various intracellular pathways of glucose metabolism.

Therefore, to evaluate the effects of chronic hyperinsulinaemia on the various steps of glucose metabolism distal to receptor binding, we have studied glucose transport, glucose oxidation, and glucose conversion to triglycerides in adipocytes from chronically hyperinsulinaemic rats.

\section{Materials and Methods}

\section{Materials}

Porcine monocomponent insulin was generously supplied by Dr. Ronald Chance of the Eli Lilly Co. (Indianapolis, Ind.). Bovine serum albumin (fraction V) was purchased from Armour and Co. (Pheonix, Arizona), collagenase from Worthington Biochemicals (Freehold, New Jersey), and $[1-14 \mathrm{C}]$ glucose, $\left[6-{ }^{14} \mathrm{C}\right.$-glucose $],[9$ $\left.10-{ }^{3} \mathrm{H}\right]$ oleic acid from New England Nuclear (Boston, Mass.).

\section{Animals}

Male Sprague-Dawley rats were used for all experiments. $100-200 \mathrm{~g}$ rats were divided into two groups. One group was injected subcutaneously with NPH insulin every $12 \mathrm{~h} \mathrm{(1/3}$ at 9 am and $2 / 3$ at $9 \mathrm{pm}$ ) in gradually increasing dosages (from $0.5 \mathrm{U}$ to $6 \mathrm{U}$ per day) for 14 days $[18,19]$. An identical volume of NPH insulin diluent was injected into control animals. To prevent hypoglycaemia all animals had free access to sugar cubes and $5 \mathrm{~g} / 100 \mathrm{~m}$ glucose drinking water, in addition to normal rat chow $[18,19]$. Both groups were fed ad lib until the morning of all studies. On the 
Table 1. Characteristics of experimental animals

\begin{tabular}{|c|c|c|}
\hline & Controls $(n=24)$ & $\begin{array}{l}\text { Hyperinsulinaemic } \\
\text { animals }(n=21)\end{array}$ \\
\hline Body weight (g) & $206 \pm 9$ (S.E.M.) & $209 \pm 10$ \\
\hline Weight gain (g/day) & $6.8 \pm 0.4$ & $6.9 \pm 0.5$ \\
\hline \multicolumn{3}{|l|}{ Food intake } \\
\hline Rat chow (g/day) & $20.1 \pm 0.8$ & $20.8 \pm 0.9$ \\
\hline Sugar cubes (g/day) & $1.2 \pm 0.4$ & $1.4 \pm 0.6$ \\
\hline Glucose $(5 \mathrm{~g} / 100 \mathrm{ml})$ & & \\
\hline in water $(\mathrm{ml} /$ day $)$ & $48 \pm 4$ & $45 \pm 3$ \\
\hline Adipocyte volume (pl) & $73 \pm 6$ & $102 \pm 8$ \\
\hline $\begin{array}{l}\text { Plasma insulin } \\
(\mu \mathrm{U} / \mathrm{ml})^{\mathrm{a}}\end{array}$ & $32 \pm 4$ & $69 \pm 8$ \\
\hline $\begin{array}{l}\text { Plasma glucose } \\
(\mathrm{mg} / 100 \mathrm{ml})\end{array}$ & $153 \pm 3$ & $86 \pm 2$ \\
\hline $\begin{array}{l}\text { Intracellular water } \\
\text { space }(\mathrm{pl} / \mathrm{cell})\end{array}$ & $1.95 \pm 0.24$ & $2.98 \pm 0.38$ \\
\hline
\end{tabular}

${ }^{a}$ Values obtained at $0900 \mathrm{~h}, 12 \mathrm{~h}$ after the last insulin injection

15th day, rats were sacrificed and blood was collected for the determination of plasma glucose and insulin. Food intake and body weight were measured daily.

\section{Preparation of Isolated Adipocytes}

All studies were begun at $0900 \mathrm{~h}$. Animals were stunned by a blow to the head, decapitated, and epididymal fat pads were removed. Isolated fat cells were prepared by shaking at $37^{\circ} \mathrm{C}$ for $60 \mathrm{~min}$ in Krebs-Ringer bicarbonate buffer, containing collagenase $(3 \mathrm{mg} /$ $\mathrm{ml})$ and BSA $(40 \mathrm{mg} / \mathrm{ml})$, according to the method of Rodbell [20]. Cells were filtered through $250 \mu \mathrm{M}$ nylon mesh, centrifuged at $400 \mathrm{rpm}$ for $4 \mathrm{~min}$, and washed twice in buffer [21]. Adipocyte counts were performed according to a modification of method III of Hirsch and Gallian [22], in which the cells were fixed in $2 \mathrm{~g} /$ $100 \mathrm{mi}$ osmium tetroxide in $0.05 \mathrm{~mol} / \mathrm{h}$ collidine buffer, $\mathrm{pH} 7.4$ (made isotonic with saline) for $24 \mathrm{~h}$ at $37^{\circ} \mathrm{C}$ and then taken up in a known volume of $0.154 \mathrm{~mol} / 1 \mathrm{NaCl}$ for counting with a Coulter Counter Model ZB. Adipocyte size was determined with a calibrated microscope by the method of Di Girolamo [23].

\section{Glucose Oxidation Studies}

The ability of adipocytes to oxidize glucose was determined according to the method of Rodbell [20]. Adipocytes were incubated at $37^{\circ} \mathrm{C}$ with either $\left[6^{-14} \mathrm{C}\right]$ glucose $(45 \mathrm{mCi} / \mathrm{mmol})$ or $[1$ $\left.{ }^{14} \mathrm{C}\right]$ glucose $(45 \mathrm{mCi} / \mathrm{mmol})$ in Krebs-Ringer bicarbonate buffer, $\mathrm{pH} 7.4$, containing bovine serum albumin $(40 \mathrm{mg} / \mathrm{ml})$. Following $1 \mathrm{~h}$ of incubation the generated ${ }^{14} \mathrm{CO}_{2}$ was collected and counted in a liquid scintillation counter.

\section{Glucose Conversion to Lipids}

Conversion of $\left[1^{14} \mathrm{C}\right]$ glucose and $\left[6{ }^{14} \mathrm{C}\right]$ glucose to total lipids, glyceride-glycerol, and fatty acids was determined according to the method of Rodbell [20] as previously described [12]. Total cell lipids were extracted, and a portion of this extract was saponified in a $1: 1$ solution of $50 \%$ ethanol plus $30 \% \mathrm{KOH}$ for free fatty acid extraction. Glucose converted to glyceride-glycerol was calculated by subtracting the radioactivity in fatty acids from that in total lipids.

\section{Glucose Transport Studies}

Transport studies were performed using a cell centrifugation technique and the details of this method have been previously described $[11,24,25]$. Isolated adipocytes were incubated with 2deoxy- $\left[1-{ }^{14} \mathrm{C}\right]-\mathrm{D}$-glucose (specific activity $2 \mathrm{mCi} / \mathrm{mmol}$ ) at various concentrations in Krebs-Ringer bicarbonate, $\mathrm{pH} 7.4$, containing BSA $(10 \mathrm{mg} / \mathrm{ml})$ at $24^{\circ} \mathrm{C}$. This assay measures the total uptake of the radiolabelled 2-deoxyglucose and is based on the principle that while 2-deoxyglucose is transported and phosphorylated by the same processes as D-glucose it cannot be further metabolized [26]. The assay was terminated after $3 \mathrm{~min}$ by transferring $200 \mathrm{ul} \mathrm{ali-}$ quots from the assay mixture to plastic microtubes containing $100 \mu \mathrm{l}$ silicone oil. The tubes were centrifuged for $30 \mathrm{sec}$ in a Beckman microfuge, and the assay considered terminated at the beginning of centrifugation. In experiments in which the stimulatory effect of insulin on uptake was measured, the cells were preincubated with insulin for $90 \mathrm{~min}$ at $24^{\circ} \mathrm{C}$. The amount of monosaccharide trapped in the extracellular water space of the cell layers was determined using $\left[{ }^{14} \mathrm{C}\right]$ inulin according to the method of Gliemann [27]. Extracellular water space was measured in each experiment, and all data for sugar uptake were corrected for this factor. The percent of the total amount of sugar available which was trapped in the extracellular water space averaged $0.033 \pm$ 0.001 at a concentration of $2 \times 10^{5} \mathrm{cells} / \mathrm{ml}$. The amount of trapped sugar ranged from $2-10 \%$ of the total sugar uptake depending on the condition of incubation.

\section{Intracellular Water Space}

Intracellular water space was determined by simultaneous assessment of the sucrose and 3-0-methyl glucose spaces after a 20 min equilibration. The 3-0-methyl glucose space (total water) minus the sucrose space (extracellular water) equals the intracellular water space [27].

\section{Analytical Methods}

Plasma glucose was determined by the glucose oxidase method using a Beckman Glucose Analyzer, and plasma insulin was determined by the double antibody radioimmunoassay technique of Desbuquois and Auerbach [28]. The antisera used was an antipork insulin antibody. Pork insulin standards were used to calculate values in the experimentally hyperinsulinaemic animals and rat insulin standards were used for control animals. The coefficient of variation of the assay was $<10 \%$.

\section{Statistical Analysis}

All $p$ values were obtained by use of the Student $t$ test. Data are expressed as mean \pm SEM.

\section{Results}

\section{Experimental Animals}

Some characteristics of the experimental animals are given in Table 1. Weight gain and food consumption of each dietary constituent was identical in both groups. However, some redistribution of body mass probably did result from the hyperinsulinaemia since fat cell size was approximately $50 \%$ greater in the 


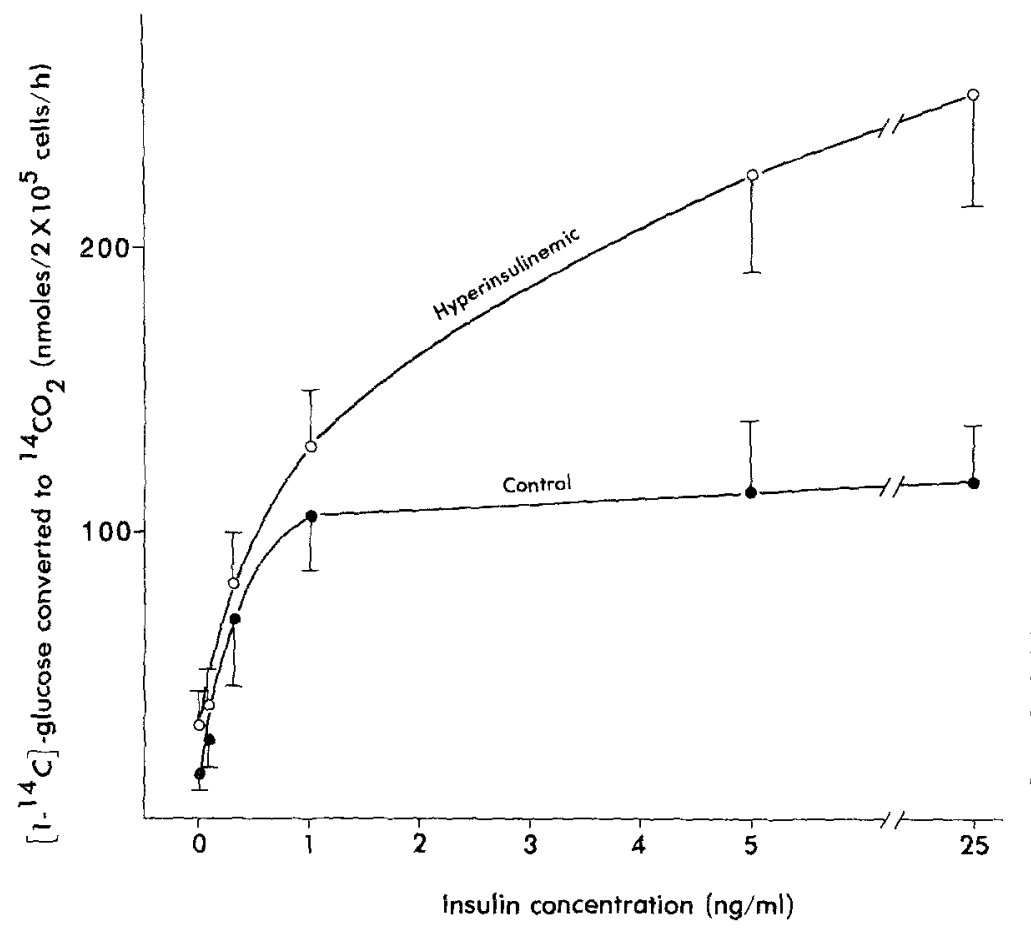

Fig. 1. Ability of adipocytes from hyperinsulinaemic (O) and control animals ( $)$ to oxidize $\left[1{ }^{14} \mathrm{C}\right] \mathrm{glu}-$ cose. Data represent the mean ( \pm SEM) of 5 separate experiments for each group. Incubations were carried out at $37^{\circ} \mathrm{C}$ for one hour at a glucose concentration of $2 \mathrm{mmol} / 1$

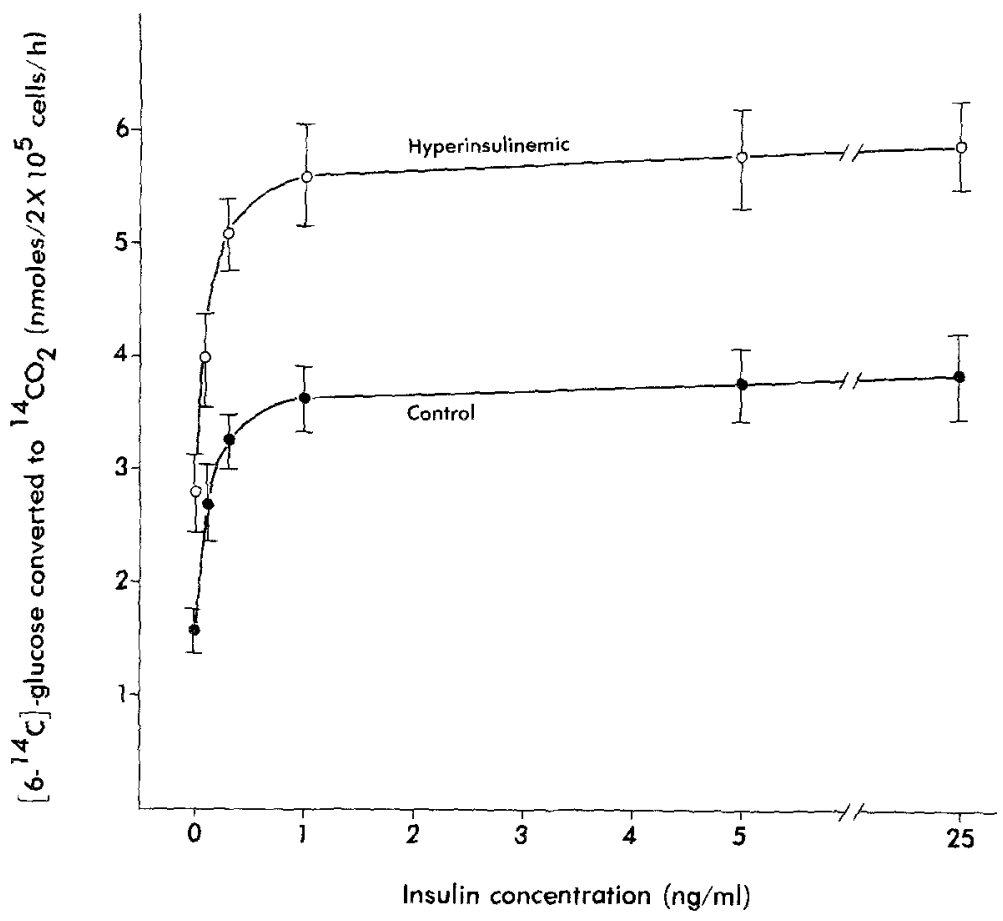

Fig. 2. Ability of adipocytes from hyperinsulinaemic (O) and control animals ( ) to oxidize $\left[6-{ }^{14} \mathrm{C}\right] \mathrm{glu}-$ cose. Data represent the mean $( \pm S E M)$ of 5 separate experiments for each group. Incubations were carried out at $37^{\circ} \mathrm{C}$, for one hour at a glucose concentration of $0.5 \mathrm{mmol} / \mathrm{t}$

insulin treated animals. The intracellular water space (pl/cell) was also significantly increased (in both absolute and percentage terms) in cells from the experimentally hyperinsulinaemic rats. Twelve hours after the last insulin injection, plasma insulin levels were significantly greater and plasma glucose levels were lower in the insulin-treated animals. The gradually increasing nature of the insulin dosage schedule was critical in allowing the animals to adapt to incremental hyperinsulinaemia. In this manner significant hypoglycaemia was avoided and food intake plus weight gain were kept equal to controls [19]. 

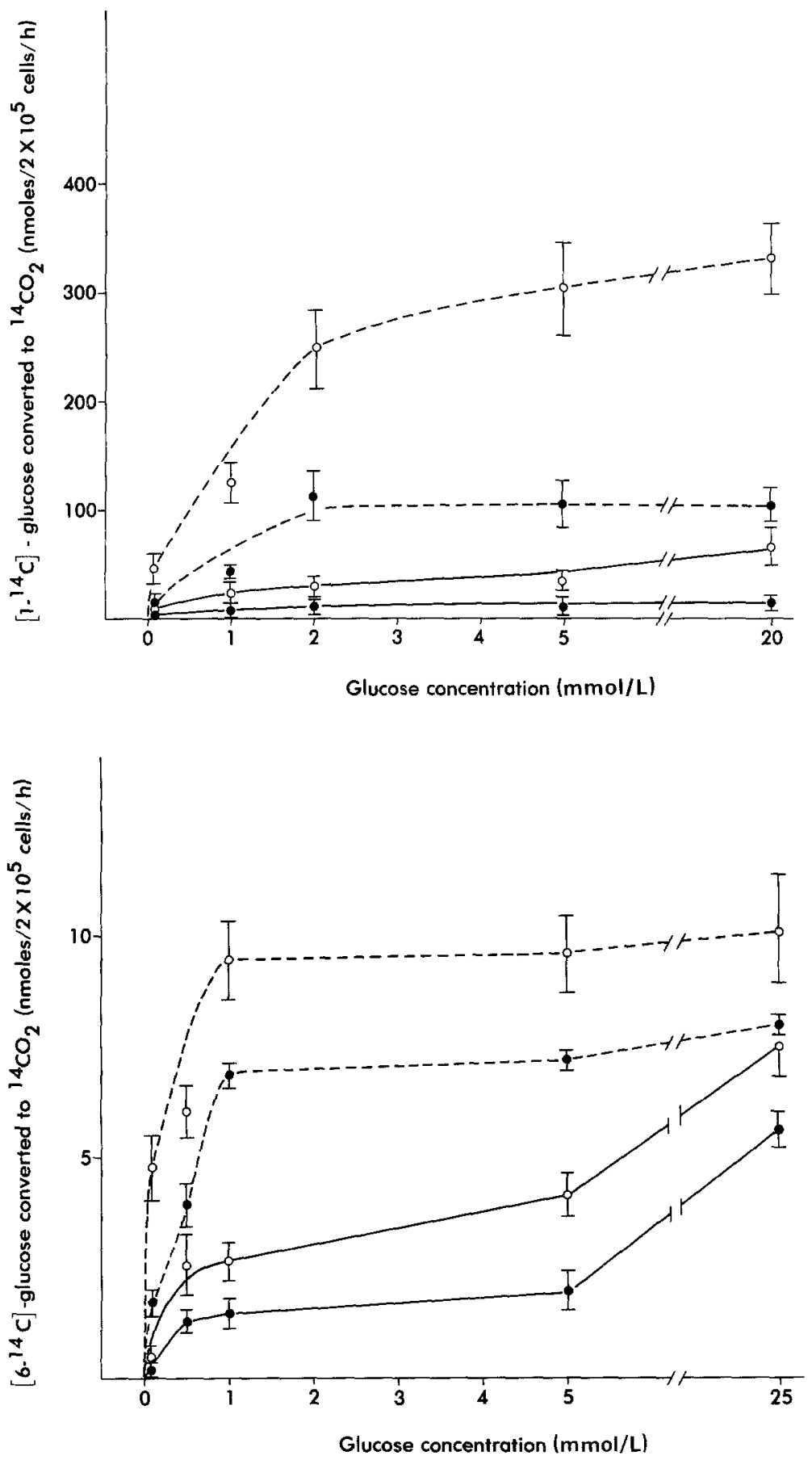

Fig. 3. Effect of glucose concentration on $\left[1-1{ }^{14} \mathrm{C}\right]$ glucose oxidation by adipocytes from hyperinsulinaemic $(\bigcirc)$ and control $(\bullet)$ animals. Cells were incubated with increasing glucose concentrations in the absence (-) and presence (-.---) of a maximally effective insulin concentration $(50 \mathrm{ng} / \mathrm{ml})$. Data represent the mean of 3 separate experiments for each group

Fig. 4. Effect of glucose concentration on $\left[6-{ }^{14} \mathrm{C}\right] \mathrm{glu}$ cose oxidation by adipocytes from hyperinsulinaemic (O) and control $(\bullet)$ animals. Cells were incubated with increasing glucose concentrations in the absence $(--)$ and presence (-...-) of a maximally effective insulin concentration $(50 \mathrm{ng} / \mathrm{ml})$. Data represent the mean of 3 separate experiments for each group

\section{Glucose Oxidation Studies}

Fig. 1 shows the insulin dose response curves for [1$\left.{ }^{14} \mathrm{C}\right]$ glucose oxidation by cells from hyperinsulinaemic and control rats. The ability of adipocytes from hyperinsulinaemic animals to oxidize $\left[1-{ }^{14} \mathrm{C}\right]$ glucose was greater than control and the differences between the two curves were greater in the basal state and at the higher insulin concentrations. Raising the insulin level to $100 \mathrm{ng} / \mathrm{ml}$ produced no further increase in glucose oxidation in either group.
Figure 2 summarizes the insulin dose-response curves for $\left[6-{ }^{14} \mathrm{C}\right]$ glucose conversion to ${ }^{14} \mathrm{CO}_{2}$. In contrast to the $\left[1-{ }^{14} \mathrm{C}\right]$ glucose oxidation data presented in Figure 1, oxidation of $\left[6-{ }^{14} \mathrm{C}\right]$ glucose was increased at all points for the hyperinsulinaemic group.

To examine the capacity of these different intracellular pathways to metabolize glucose, ${ }^{14} \mathrm{CO}_{2}$ production from $\left[1-{ }^{14} \mathrm{C}\right]$ glucose (Fig. 3 ) and $\left[6-{ }^{14} \mathrm{C}\right]$ glucose (Fig. 4), was measured at different glucose concentrations in the presence or absence of a maxi- 
Table 2. Conversion of glucose to total lipids, glyceride-glycerol and fatty acids by adipocytes from hyperinsulinaemic rats and controls

\begin{tabular}{|c|c|c|c|c|c|c|}
\hline & \multicolumn{2}{|c|}{ Total lipids } & \multicolumn{2}{|c|}{ Glyceride glycerol } & \multicolumn{2}{|c|}{ Fatty acid } \\
\hline & Basal & Insulin & $\begin{array}{l}\text { Basal } \\
\text { nmol gl }\end{array}$ & $\begin{array}{l}\text { Insulin } \\
\text { eells/h }\end{array}$ & Basal & Insulin \\
\hline \multicolumn{7}{|l|}{ Control } \\
\hline$\left[1-{ }^{14} \mathrm{C}\right]$-glucose & $16 \pm 2$ & $130 \pm 10$ & $13 \pm 2$ & $38 \pm 12$ & $3 \pm 2$ & $92 \pm 11$ \\
\hline$[6-14 \mathrm{C}]$-glucose & $19 \pm 2$ & $182 \pm 6$ & $11 \pm 2$ & $52 \pm 8$ & $8 \pm 2$ & $130 \pm 6$ \\
\hline \multicolumn{7}{|l|}{ Hyperinsulinaemic } \\
\hline$\left[1-{ }^{14} \mathrm{C}\right]$-glucose & $18 \pm 2$ & $176 \pm 6^{a}$ & $15 \pm 2$ & $42 \pm 12$ & $3 \pm 2$ & $134 \pm 10^{\mathrm{a}}$ \\
\hline$\left[6-{ }^{14} \mathrm{C}\right]$-glucose & $22 \pm 2$ & $205 \pm 6^{a}$ & $15 \pm 4$ & $59 \pm 6$ & $7 \pm 2$ & $146 \pm 5^{\mathrm{a}}$ \\
\hline
\end{tabular}

Data are the mean of 8 experiments, and represent the mean ( $\pm \mathrm{SEM})$. Medium glucose concentration, 2 mmol/1, insulin concentration, $50 \mathrm{ng} / \mathrm{ml}$

a $<0.05$ compared with controls

Table 3. Glucose transport by adipocytes from control and hyperinsulinaemic rats

\begin{tabular}{lcccc}
\hline & \multicolumn{4}{l}{ 2-deoxy glucose concentration $(\mathrm{mmol} / \mathrm{l})$} \\
\cline { 2 - 5 } & 2 & 5 & 10 & 20 \\
\hline $\begin{array}{l}\text { Control } \\
\text { Hyper- } \\
\text { insulinaemic }\end{array}$ & $10.2 \pm 0.8$ & $9.4 \pm 1.0$ & $10.8 \pm 1.1$ & $12.4 \pm 1.0$ \\
\end{tabular}

Cells were preincubated with a maximally effective insulin concentration $(50 \mathrm{ng} / \mathrm{ml})$ for $60 \mathrm{~min}$ at $24^{\circ}$. Uptake was then measured after a $3 \mathrm{~min}$ incubation with the indicated 2-deoxy glucose concentrations. Results represent the mean ( \pm SEM) of 5 separate experiments for the hyperinsulinaemic group and 8 for the control group and are expressed as nmoles $/ 3 \mathrm{~min} / 2 \times 10^{5}$ cells

mally effective insulin level. Figs. 3 and 4 demonstrate that the capacity of cells from the hyperinsulinaemic animals to oxidize glucose was always greater than control.

\section{Incorporation of Glucose into Lipid}

Glucose conversion to triglycerides was also measured (Table 2). It can be seen that under basal conditions adipocytes from both groups converted comparable amounts of glucose into total lipids. In the presence of insulin, adipocytes from the hyperinsulinaemic animals converted significantly more glucose (both $1{ }^{14} \mathrm{C}$ and $6-{ }^{14} \mathrm{C}$ ) into triglyceride. When the labelled triglyceride was fractionated into glyceride-glycerol and fatty acids, cells from hyperinsulinaemic rats incorporated more glucose into the fatty acid moiety, from both $\left[1-{ }^{14} \mathrm{C}\right]$ and $\left[6-{ }^{14} \mathrm{C}\right]$ glucose. In contrast, glucose conversion to glycerideglycerol was similar in the 2 groups.

\section{Relationship between Glucose Transport and Intracellular Glucose Metabolism}

Several aspects of intracellular glucose metabolism measured in cells from the hyperinsulinaemic animals are thus equal to or increased over control. To deter- mine whether this was due to increased glucose transport or increased intracellular metabolism, 2-deoxy glucose uptake was determined in the presence of a maximally effective insulin level $(50 \mathrm{ng} / \mathrm{ml})$ at increasing hexose concentrations. As previously reported $(18,19)$, Table 3 demonstrates that at each 2-deoxy glucose level, glucose transport activity was greater in cells from hyperinsulinaemic animals. However, at $10 \mathrm{mmol} / \mathrm{l}$ 2-deoxy glucose, control rates of transport were equal to the rates observed in cells from hyperinsulinaemic animals at $2 \mathrm{mmol} / \mathrm{l}$. In contrast, at $2 \mathrm{mmol} / \mathrm{l}$ glucose the amount of glucose oxidized (either $1{ }^{14} \mathrm{C}$ or $6{ }^{14} \mathrm{C}$ ) by cells from hyperinsulinaemic animals was still greater than control cells at $10 \mathrm{mmol} / \mathrm{l}$ glucose (Fig. 3 and 4 ).

\section{Discussion}

The results demonstrate that chronic experimental hyperinsulinaemia is associated with enhanced rates of adipocyte glucose metabolism. Thus, $\mathrm{CO}_{2}$ production from glucose labelled in either the one or six position and insulin-stimulated glucose incorporation into cell triglycerides was greater in cells from hyperinsulinaemic rats. This is in contrast to the situation in obesity in which adipocytes from hyperinsulinaemic, obese animals display markedly decreased rates of $\left[1-{ }^{-14} \mathrm{C}\right]$ glucose oxidation and fatty acid synthesis from labelled glucose [7, 11-13]. These contrasting results suggest the possibility that in adipocytes from older, obese animals the intracellular defects in glucose metabolism are not due to hyperinsulinaemia per se, but are most likely related to some other aspect of the obese condition. In these studies rats were made hyperinsulinaemic for 14 days, while obese animals are hyperinsulinaemic for a much greater period of time. Therefore, although 2 weeks is a relatively long time in a rat's lifespan, it is still possible that longer periods of hyperinsulinaemia would lead to the metabolic defects described in enlarged adipocytes from obese animals. 
It should be noted that cell size increased in the insulin-treated animals leading to an increase in surface area and cytoplasmic volume. We have expressed all results on a per cell basis, and although the best method of data normalization is not known, calculating the results on the basis of unit surface area or cytoplasmic volume would tend to diminish the magnitude of the differences recorded.

The enhanced rates of glucose metabolism found in adipocytes from hyperinsulinaemic animals are not simply due to increased glucose transport. Thus, elevated rates of glucose metabolism were found at high medium glucose concentrations, in the presence of insulin - conditions under which transport is not felt to be rate limiting for glucose metabolism [29, 30]. More importantly, at a medium hexose concentration of $2 \mathrm{mmol} / 1$, cells from hyperinsulinaemic animals oxidize more glucose than control cells (at $10 \mathrm{mmol} / \mathrm{l}$ glucose) under conditions where glucose transport activity is the same. Thus, both glucose transport and intracellular glucose metabolism are increased in cells from the hyperinsulinaemic animals.

Acknowledgement. This work was supported by funds of the Medical Research Service of the Veterans Administration and by NIH NIAMDD grants \#19905 and AM 20993.

\section{References}

1. Rabinowitz, D., Zierler, K. L.: Forearm metabolism in obesity and its response to intra-arterial insulin. Characterization of insulin resistance and evidence for adaptive hyperinsulinism. $\mathrm{J}$. Clin. Invest. 44, 2173-2181 (1962)

2. Grey, W., Kipnis, D. M.: Effect of diet composition on the hyperinsulinemia of obesity. N. Engl. J. Med. 285, 827-831 (1971)

3. Olefsky, J. M., Crapo, P. A., Ginsberg, H., Reaven G. M.: Metabolic effects of increased caloric intake in man. Metabolism 24, 495-503 (1975)

4. Gavin, J. R., III, Roth, J., Jen, P., Freychet, P.: Insulin receptors in human circulating cells and fibroblasts. Proc. Natl. Acad. Sci. USA 69, 747-751 (1972)

5. Conti, M., Harwood, J. P., Dufau, M.L., Catt, K. J.: Effect of gonadotropin-induced receptor regulation on biological responses of isolated rat luteal cells. J. Biol. Chem. 252, 8869-8874 (1977)

6. Tsuruhara, T., Dufau, M. L., Cigorraga, S., Catt, K. J.: Hormonal regulation of testicular lutenizing hormone receptors. $\mathrm{J}$. Biol. Chem. 252, 9002-9009 (1977)

7. Di Girolamo, M., Rudman, D.: Variations in glucose metabolism and sensitivity to insulin of the rat's adipose tissue, in relation to age and body weight. Endocrinology 82, 1133-1141 (1968)

8. Salans, L. B., Dougherty, J. W.: The effect of insulin upon glucose metabolism by adipose cells of different size. Influence of cell lipid and protein content, age and nutritional state. J. Clin. Invest. 50, 1399-1410 (1971)

9. Gliemann, J.: Insulin-like activity of dilute human serum assayed by isolated adipose cell method. Diabetes 14, 643-649 (1965)

10. Livingston, J. N., Cuatrecasas, P., Lockwood, D. H.: Insulin insensitivity of large fat cells. Science 177, 626-628 (1972)
11. Olefsky, J. M.: The effects of spontaneous obesity on insulin binding, glucose transport and glucose oxidation of isolated rat adipocytes. J. Clin. Invest. 57, 842-851 (1976)

12. Olefsky, J. M.: Mechanism of decreased insulin responsiveness of large adipocytes. Endocrinology 100, 1169-1177 (1977)

13. Czech, M.P.: Cellular basis of insulin sensitivity in large rat adipocytes. J. Clin. Invest. 57, 1523-1532 (1976)

14. Pilot, H. C., Yatvin, M. B.: Interrelationships of mammalian hormones and enzyme levels in vivo. Physiol. Rev. 53, 228-325 (1973)

15. Lardy, H. A., Foster, D. O., Young, J. W., Shrago, E., Ray, P.D.: Hormonal control of enzymes participating in gluconeogenesis and lipogenesis. J. Cell. Physiol. 66, 39-54 (1965)

16. Weber, G., Singhal, R. L., Stamm, N. B., Lea, M. A., Fisher, E. A.: Synchronous behavior pattern of key glycolytic enzymes: Glucokinase, phosphofructokinase, and pyruvate kinase. Adv. Enzyme Regul. 4, 59-81 (1966)

17. Milstein, S. W., Hausberger, F.X.: Lipogenesis and carbohydrate utilization. Diabetes 5, 89-92 (1956)

18. Kobayashi, M., Olefsky, J. M.: Effect of experimental hyperinsulinemia on insulin binding and glucose transport in isolated adipocytes. Am. J. Physiol. 235, E53-E62 (1978)

19. Kobayashi, M., Olefsky, J. M.: Longterm regulation of adipocyte glucose transport capacity by circulating insulin in rats. $\mathbf{J}$. Clin. Invest. 62, 73-81 (1978)

20. Rodbell, M.: Metabolism of isolated fat cells. I. Effects of hormones on glucose metabolism and lipolysis. J. Biol. Chem. 239, 375-380 (1964)

21. Olefsky, J. M., Reaven, G. M.: Effects of age and obesity on insulin binding to isolated adipocytes. Endocrinology 96, 1486-1498 (1975)

22. Hirsch, J., Gallian, E.: Methods for the determination of adipose cell size in man and animals. J. Lipid Res. 9, 115-119 (1968)

23. Di Girolamo, M., Medlinger, S., Fertig, J. W.: A simple method to determine fat cell size and number in four mammalian species. Am. J. Physiol. 221, 850-858 (1971)

24. Olefsky, J. M.: Effect of dexamethasone on insulin binding, glucose transport and glucose oxidation of isolated rat adipocytes. J. Clin. Invest. 56, 1499-1508 (1975)

25. Olefsky, J. M.: Effects of fasting on insulin binding, glucose transport and glucose oxidation in isolated rat adipocytes. J. Clin. Invest. 58, 1450-1460 (1976)

26. Wick, A. N., Drury, D. R., Hakada, H. I., Wolfe, J. B.: Localization of the primary metabolic block produced by 2-deoxy glucose. J. Biol. Chem. 224, 963-969 (1957)

27. Gliemann, J., Osterlind, K., Vinten, J., Gammeltoft, S.: A procedure for measurement of distribution spaces in isolated fat cells. Biochim. Biophys. Acta 286, 1-9 (1972)

28. Desbuquois, B., Aurbach, E. D.: Use of polyethylene glycol to separate free and antibody-bound peptide in radioimmunoassay. J. Clin. Endocrinol. Metab. 33, 732-738 (1971)

29. Chang, K. J., Cuatrecasas, P.: Adenosine triphosphate-dependent inhibition of insulin-stimulated glucose transport in fat cells. J. Biol. Chem. 249, 3170-3180 (1974)

30. Crofford, O. B., Renold, A. E.: Glucose uptake by incubated rat epididymal adipose tissue. J. Biol. Chem. 240, 14-21 (1965)

Received: August 9, 1978, and in revised form: April 11, 1979

Jerrold M. Olefsky, M. D.

University of Colorado Medical Center

Department of Medicine

B151, 4200 East Ninth Avenue

Denver, CO 80262, USA 